\section{Pacific Northwest}

National Laboratory

Operated by Battelle for the

U.S. Department of Energy

\title{
Ultrasonic Examination of Double-Shell Tank 241-SY-102 Examination Completed June 2004
}

\author{
A.F. Pardini \\ G.J. Posakony
}

June 2004

Prepared for the U.S. Department of Energy under Contract DE-AC06-76RL01830 


\title{
DISCLAIMER
}

This report was prepared as an account of work sponsored by an agency of the United States Government. Neither the United States Government nor any agency thereof, nor Battelle Memorial Institute, nor any of their employees, makes any warranty, express or implied, or assumes any legal liability or responsibility for the accuracy, completeness, or usefulness of any information, apparatus, product, or process disclosed, or represents that its use would not infringe privately owned rights. Reference herein to any specific commercial product, process, or service by trade name, trademark, manufacturer, or otherwise does not necessarily constitute or imply its endorsement, recommendation, or favoring by the United States Government or any agency thereof, or Battelle Memorial Institute. The views and opinions of authors expressed herein do not necessarily state or reflect those of the United States Government or any agency thereof.

\author{
PACIFIC NORTHWEST NATIONAL LABORATORY \\ operated by \\ BATTELLE \\ for the \\ UNITED STATES DEPARTMENT OF ENERGY \\ under Contract DE-AC06-76RL01830
}

Printed in the United States of America
Available to DOE and DOE contractors from the Office of Scientific and Technical Information,
P.O. Box 62, Oak Ridge, TN 37831-0062;
ph: (865) 576-8401
fax: $(865) 576-5728$
email: reports@adonis.osti.gov

\footnotetext{
Available to the public from the National Technical Information Service, U.S. Department of Commerce, 5285 Port Royal Rd., Springfield, VA 22161 ph: (800) 553-6847 fax: $(703) 605-6900$ email: orders@ntis.fedworld.gov online ordering: http://www.ntis.gov/ordering.htm
}

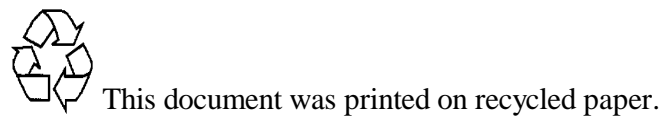


PNNL-14749 Rev. 0

\title{
Ultrasonic Examination of Double-Shell Tank 241-SY-102 Examination Completed June 2004
}

\author{
AF Pardini \\ GJ Posakony
}

June 2004

Prepared for

the U.S. Department of Energy under Contract DE-AC06-76RL01830

Pacific Northwest National Laboratory

Richland, Washington 99352 


\section{Summary}

COGEMA Engineering Corporation (COGEMA), under a contract from CH2M Hill Hanford Group (CH2M Hill), has performed an ultrasonic nondestructive examination of selected portions of DoubleShell Tank 241-SY-102. The purpose of this examination was to provide information that could be used to evaluate the integrity of the wall of the primary tank. The requirements for the ultrasonic examination of Tank 241-SY-102 were to detect, characterize (identify, size, and locate), and record measurements made of any wall thinning, pitting, or cracks that might be present in the wall of the primary tank. Any measurements that exceed the requirements set forth in the Engineering Task Plan (ETP), RPP-17750 (Jensen 2003) and summarized on page 1 of this document, are reported to CH2M Hill and the Pacific Northwest National Laboratory (PNNL) for further evaluation. Under the contract with CH2M Hill, all data is to be recorded on disk and paper copies of all measurements are provided to PNNL for third-party evaluation. PNNL is responsible for preparing a report that describes the results of the COGEMA ultrasonic examinations.

\section{Examination Results}

The results of the examination of Tank 241-SY-102 have been evaluated by PNNL personnel. The ultrasonic examination consisted of two 15-in. wide scans over the entire height of the tank and the heataffected zone (HAZ) of five vertical welds and one horizontal weld. The examination was performed to detect any wall thinning, pitting, or cracking in the primary tank wall.

\section{Primary Tank Wall Vertical Scan Paths}

Two 15-in.-wide vertical scan paths were performed on shell courses \#1, \#2, \#3, \#4, and \#5. The shell courses were examined for wall thinning, pitting, and cracks oriented vertically on the primary tank wall. There were 5 areas of wall thinning that exceeded the reportable level of $10 \%$ of the nominal thickness. The areas were all located in shell course \#1. No pitting or vertical crack-like indications were detected in shell courses \#1, \#2, \#3, \#4, or \#5.

\section{Primary Tank Wall Weld Scan Paths}

The HAZ of vertical welds in shell courses \#1, \#2, \#3, \#4, and \#5 were examined for wall thinning, pitting, and cracks oriented either perpendicular or parallel to the weld. There was one area of wall thinning that exceeded the reportable level of $10 \%$ of the nominal thickness. The area was located in shell course \#1. No pitting or crack-like indications were detected in the weld HAZ areas in shell courses $\# 1, \# 2$, \#3, \#4, and \#5.

The HAZ of the horizontal weld between shell course \#5 and the tank knuckle was examined for wall thinning, pitting and cracks oriented either perpendicular or parallel to the weld. There were no areas of wall thinning that exceeded the reportable level of $10 \%$ of the nominal thickness. No pitting or crack-like 
indications were detected in the weld areas on shell course \#5 side or on the knuckle side of the horizontal weld. 


\section{Contents}

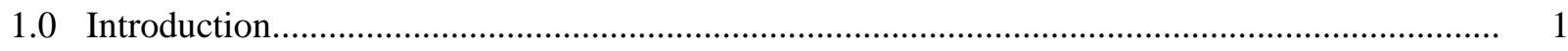

2.0 Qualified Personnel, Equipment, and Procedure ......................................................... 2

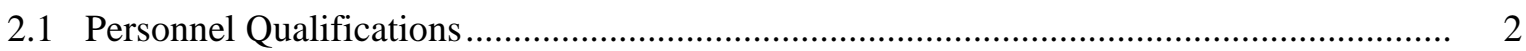

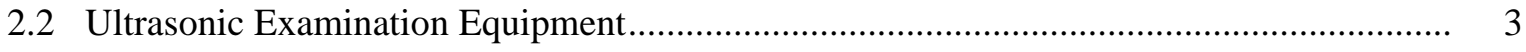

2.3 Ultrasonic Examination Procedure ............................................................................. 3

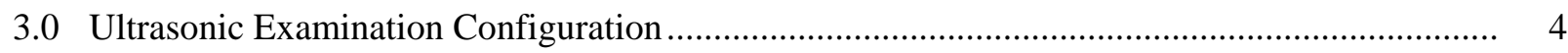

3.1 Primary Tank Wall Transducer Configuration ........................................................... 4

3.2 Weld Zone Transducer Configuration ..................................................................... 5

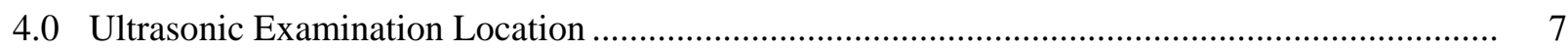

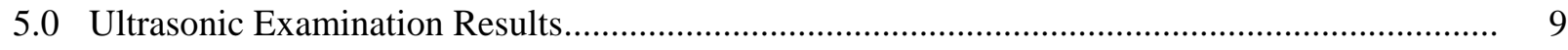

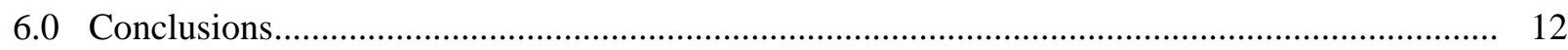

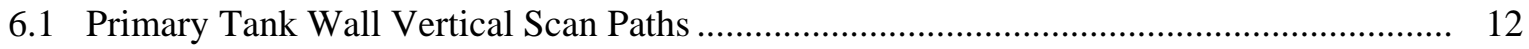

6.2 Primary Tank Wall Weld Scan Paths ......................................................................... 12

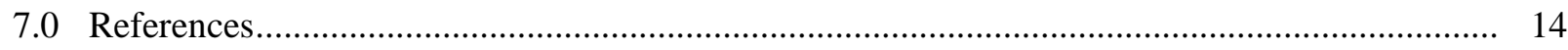




\section{Figures}

3.1 Transducer Configuration for Examining the Primary Tank Wall .................................... 4

3.2 Transducer Configurations for Examination of Weld Zone in the Primary Tank Wall ........... 5

3.3 Views of the Weld Zone to be Ultrasonically Examined in the Primary Tank Wall .............. 6

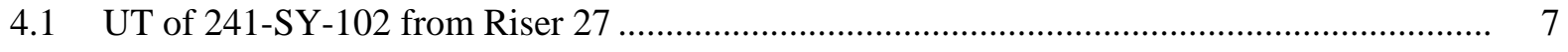

4.2 Sketch of Scan Paths on Tank 241-SY-102 …................................................................ 8

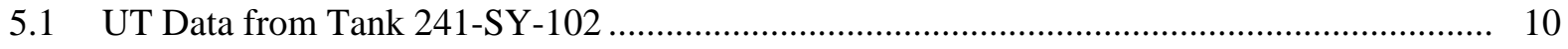

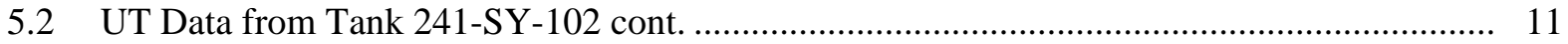




\subsection{Introduction}

COGEMA Engineering Corporation (COGEMA), under a contract from CH2M Hill Hanford Group (CH2M Hill), has performed an ultrasonic nondestructive examination (UT) of selected portions of Double-Shell Tank (DST) 241-SY-102. The purpose of this examination was to provide information that could be used to evaluate the integrity of the DST. The requirements for the UT of Tank 241-SY-102 were to detect, characterize (identify, size, and locate), and record measurements made of any wall thinning, pitting, or cracks that might be present in the wall of the primary tank. Any measurements that exceed the requirements set forth in the Engineering Task Plan (ETP), RPP-17750 (Jensen 2003), are reported to CH2M Hill and the Pacific Northwest National Laboratory (PNNL) for further evaluation. Specific measurements that are reported include the following:

- Wall thinning that exceeds $10 \%$ of the nominal thickness of the shell course plate.

- Pits with depths that exceed $25 \%$ of the nominal shell course plate thickness.

- Stress-corrosion cracks that exceed 0.10-in. (through-wall) that are detected in the inner wall of the tank, heat-affected zone (HAZ) of welds, or in the tank knuckle.

The accuracy requirements for ultrasonic measurements for the different types of defects are as follows:

- Wall thinning - measure thickness within \pm 0.020 -in.

- Pits - size depths within \pm 0.050 -in.

- Cracks - size the depth of cracks on the inner wall surfaces within \pm 0.1 -in.

- Location - locate all reportable indications within \pm 1.0 -in.

Under the contract with $\mathrm{CH} 2 \mathrm{M}$ Hill, all data is to be recorded on disk and paper copies of all measurements are provided to PNNL for third-party evaluation. PNNL is responsible for preparing a report that describes the results of the COGEMA UT. 


\subsection{Qualified Personnel, Equipment, and Procedure}

Qualification of personnel participating in the DST inspection program, the UT equipment (instrument and mechanical scanning fixture), and the UT procedure that will be used in the examination of the current DST is required by $\mathrm{CH} 2 \mathrm{M}$ Hill. Personnel participating in the examinations are to be certified in accordance with the American Society for Nondestructive Testing (ASNT) Guideline SNTTC-1A-92 and associated documentation is to be provided. The capability of the UT system is to be validated through a performance demonstration test (PDT) administered by PNNL on a mock-up simulating the actual DST. The current procedure for the UT is to be based on the Section V, Article 4, Boiler and Pressure Vessel Code defined by the American Society for Mechanical Engineers (ASME).

\subsection{Personnel Qualifications}

The following individuals were qualified and certified to perform UT of the Hanford DST 241-SY102:

- Mr. Wesley H. Nelson, ASNT Level III (\#LM-1874) in UT, has been identified as COGEMA's UT Level III authority for this project. Mr. Nelson has been certified by COGEMA as a UT Level III in accordance with COGEMA procedure COGEMA-SVCP-PRC-014, latest revision. Further documentation has been provided to establish his qualifications. Reference: Letter from PNNL to C.E. Jensen dated August 22, 2000, "Report on Performance Demonstration Test - PDT, May 2000."

- Mr. James B. Elder, ASNT Level III (\#JM-1891) in UT, has been contracted by COGEMA to provide peer review and analysis of all DST UT data. Mr. Elder has been certified by JBNDT as a UT Level III in accordance with JBNDT written practice JBNDT-WP-1, latest revision. Further documentation has been provided to establish his qualifications. Reference: PNNL-11971, Final Report - Ultrasonic Examination of Double-Shell Tank 241-AN-107.

- Mr. William D. Purdy, COGEMA UT Level II limited (for P-Scan data acquisition only). Mr. Purdy has been certified in accordance with COGEMA procedure COGEMA-SVCP-PRC-014, latest revision. Further documentation has been provided to establish his qualifications. Reference: Letter from PNNL to C.E. Jensen dated October 5, 2001, "Purdy Performance Demonstration Test (PDT) Report."

The following individual is a trainee and is not qualified or certified to perform independent UT of the Hanford DST 241-SY-102:

- Mr. Jeffery S. Pintler, COGEMA UT trainee in accordance with COGEMA procedure COGEMASVCP-PRC-014, latest revision. 


\subsection{Ultrasonic Examination Equipment}

CH2M Hill has provided the UT equipment for the examination of Tank 241-SY-102. This equipment consists of a Force Institute P-Scan ultrasonic test instrument and a Force Institute AWS-5D remote-controlled, magnetic-wheel crawler for examining the primary tank wall. Ultrasonic transducers used for the examinations are commercial off the shelf. The P-Scan ultrasonic system has been qualified through a PDT administered by PNNL. Reference: PNNL-11971, Final Report- Ultrasonic Examination of Double-Shell Tank 241-AN-107.

\subsection{Ultrasonic Examination Procedure}

COGEMA has provided the UT procedure for the examination of Tank 241-SY-102. This procedure, COGEMA-SVUT-INS-007.3, Revision 2, outlines the type of UT and mechanical equipment that are to be used as well as the types of transducers. Both straight-beam and angle-beam transducers are used for the examination of the primary tank wall and the HAZ of selected primary tank vertical and horizontal welds. The examination procedures include full documentation on methods for calibration, examination, and reporting. Hard copies of the T-Scan (thickness) and P-Scan (projection or angle beam) views of all areas scanned are made available for analysis. The UT procedure requires the use of specific UT transducers for the different examinations. A calibration performed before and after the examinations insures that each transducer used in the inspection is adjusted and that the entire system is performing correctly. The COGEMA UT procedure has been qualified through a PDT. Revisions to the procedure are reviewed to determine if a further PDT is required. Reference: PNNL-11971, Final Report Ultrasonic Examination of Double-Shell Tank 241-AN-107. 


\subsection{Ultrasonic Examination Configuration}

COGEMA is required to inspect selected portions of the DSTs which may include the primary and secondary tank walls, the HAZ of the primary tank vertical and horizontal welds, and the tank knuckle and bottoms. The P-Scan system has been configured to perform these examinations and has been performance tested. The examination of Tank 241-SY-102 included UT of the primary tank wall and the $\mathrm{HAZ}$ of selected welds in the primary tank wall.

\subsection{Primary Tank Wall Transducer Configuration}

Figure 3.1 provides an example of the scanning configuration generally used during an examination of the primary tank wall. However, other configurations can be used at the discretion of the COGEMA UT Level III (i.e., 45-degree transducers can be removed for simple wall thickness measurements). The functional diagram in Figure 3.1 shows one straight-beam and two angle-beam transducers ganged together for examining the primary tank wall. The straight beam is designed to detect and record wall thinning and pits, and the angle beams are designed to detect and record any cracking that may be present. These transducers are attached to the scanning bridge and they all move together. Information is captured every 0.035 -in. (or as set by the NDE inspector) as the assembly is scanned across a line. At the end of each scan line the fixture is indexed 0.035-in. (or as set by the NDE inspector) and the scan is repeated. The mechanical scanning fixture is designed to scan a maximum of 15-in. and then index for the next scan line. The hard copy provides a permanent record that is used for the subsequent analysis.

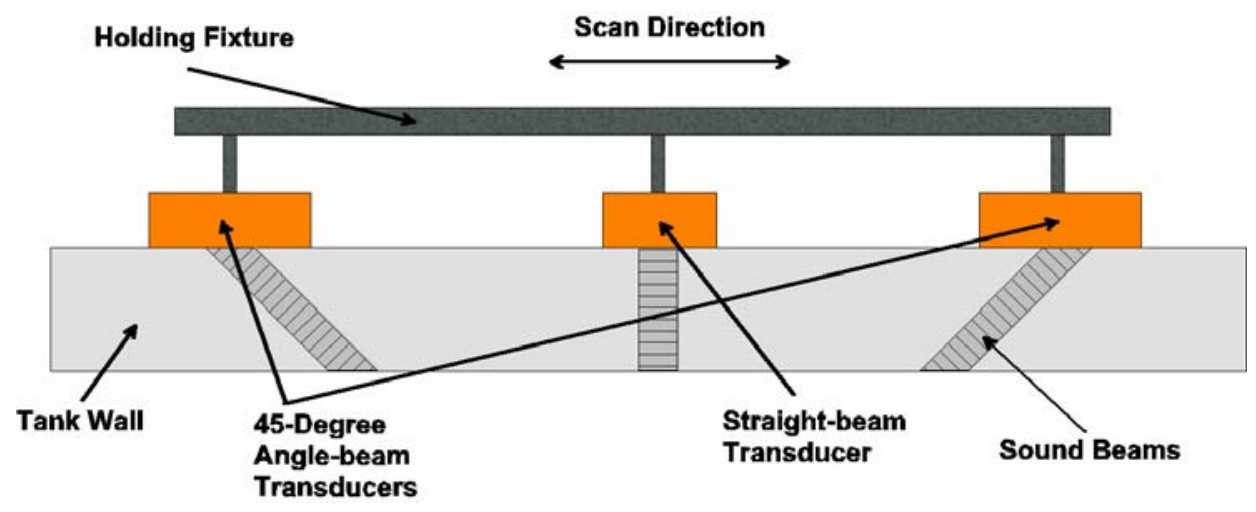

Figure 3.1. Transducer Configuration for Examining the Primary Tank Wall

\section{Transducer Specifications:}

Angle-Beam

Type: MWB-45 04E

Frequency: $4 \mathrm{MHz}$

Size: 8 X $9 \mathrm{~mm}$

Manufacturer: Krautkramer

Straight-Beam

Type: MSEB 5B

Frequency: $5 \mathrm{MHz}$

Size: Dual - 2 X 8 mm

Manufacturer: Krautkramer 


\subsection{Weld Zone Transducer Configuration}

Figure 3.2 is a functional sketch that shows the configurations for examination of the weld zone. The area of interest (HAZ of the weld) is adjacent to the weld. Both cracks and pitting may occur in this region. The "A" portion of this sketch shows the 60-degree angle-beam transducers used for detecting cracks parallel to the weld. The straight-beam transducers in this sketch are used for detecting and recording any pitting or wall thinning that may be present. All transducers are ganged together. The scanning distance traveled is limited to a total of approximately 5.0-in. The sketch titled "B" shows the arrangement for detecting cracks that may lie perpendicular to the weld. Four 45-degree, angle-beam transducers are used for this inspection. Again the transducers are ganged together but the scan is limited to a total of approximately 4.0-in. The weld zone requirements are shown in Figure 3.3. The scan protocol, data capture, and index are the same for examining other weld areas in the tank.

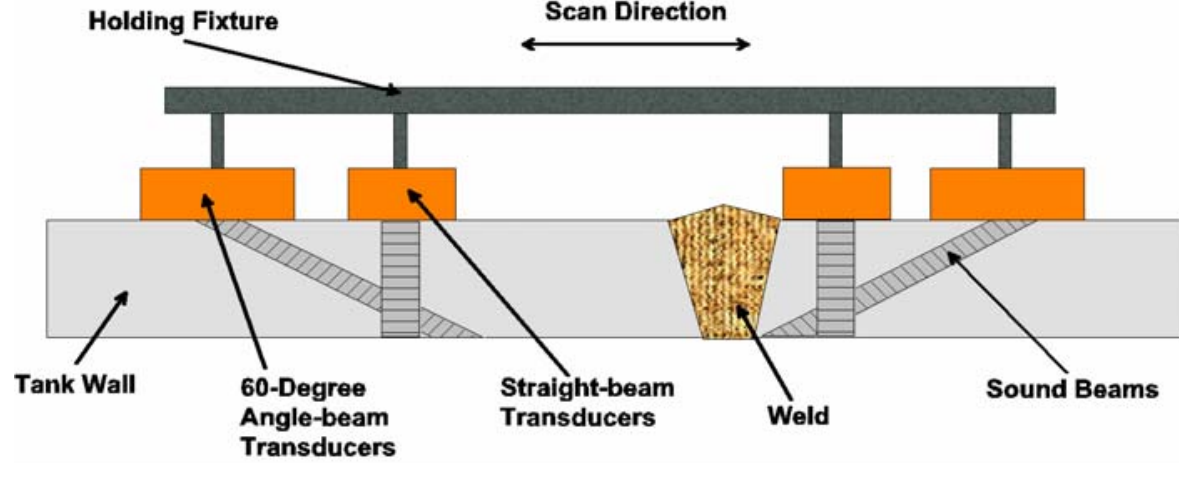

A. Configuration for pitting and cracks parallel to weld

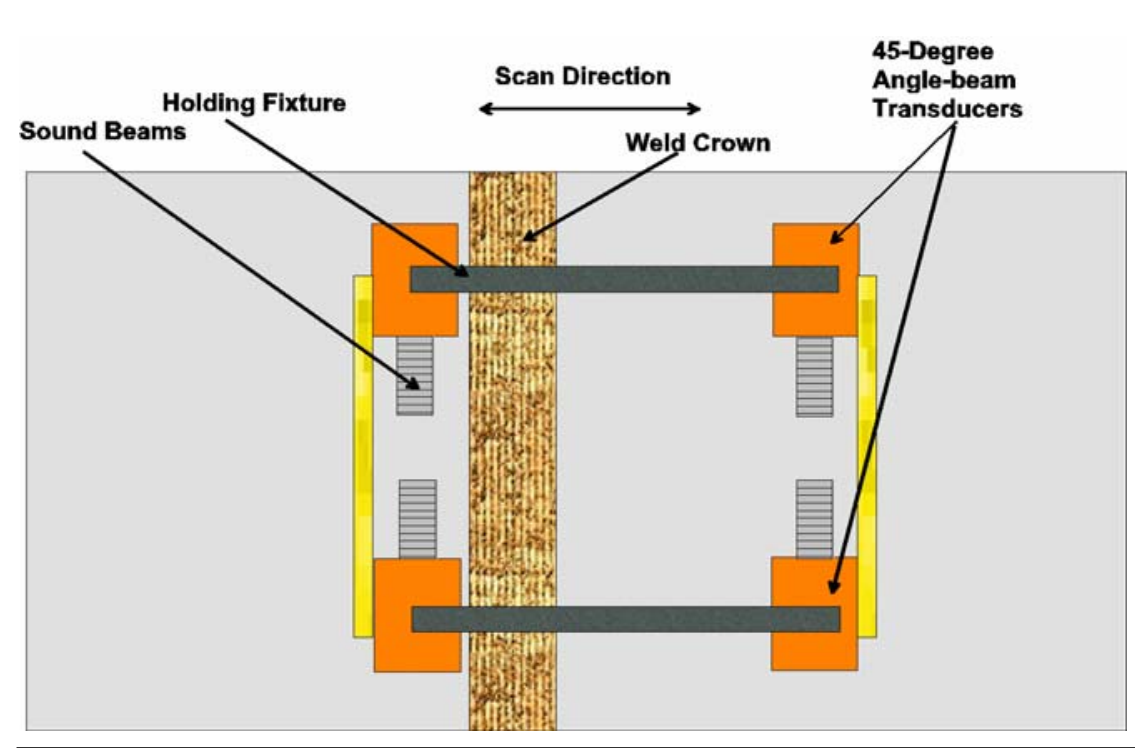

B. Configuration for cracks perpendicular to weld
Transducer Specifications: Angle-Beam

Type: MWB-60 04E

Frequency: $4 \mathrm{MHz}$

Size: $8 \times 9 \mathrm{~mm}$

Manufacturer: Krautkramer

Straight-Beam

Type: MSEB 5B

Frequency: $5 \mathrm{MHz}$

Size: Dual - 2 X 8 mm

Manufacturer: Krautkramer

\section{Transducer Specifications:}

Angle-Beam

Type: MWB-45 04E

Frequency: $4 \mathrm{MHz}$

Size: $8 \times 9 \mathrm{~mm}$

Manufacturer: Krautkramer

Figure 3.2. Transducer Configurations for Examination of Weld Zone in the Primary Tank Wall 
In the HAZ, the requirement for characterizing cracks that lie perpendicular or parallel to welds in the primary tank wall is described in Figure 3.3. The HAZs are located on either side of the weld and defined as being within 1-in. of the toe of the weld and on the inner three-quarters of the thickness (3/4T) of the shell course plate. These zones are considered most likely to experience stress-corrosion cracking.

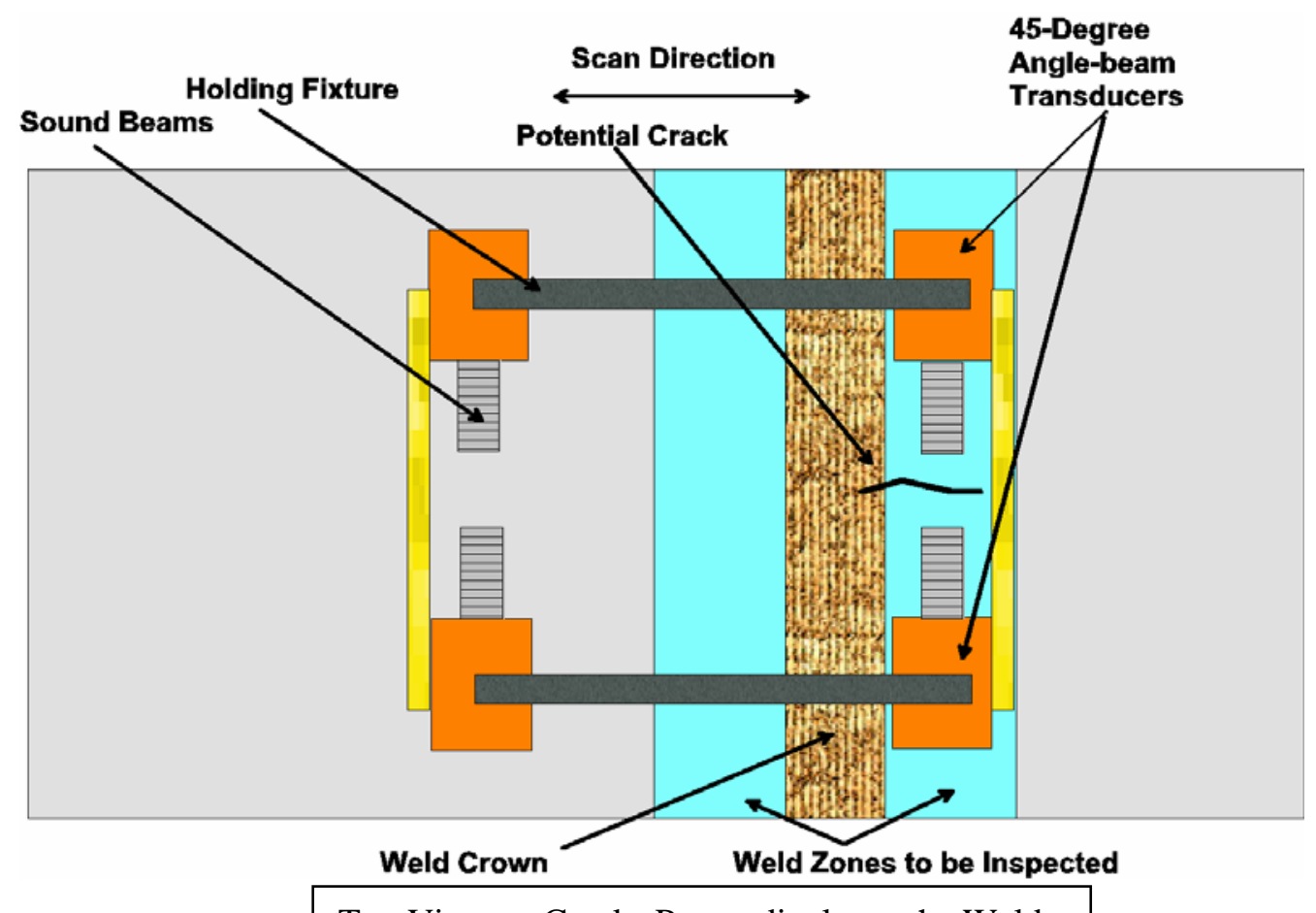

Top View --- Cracks Perpendicular to the Weld

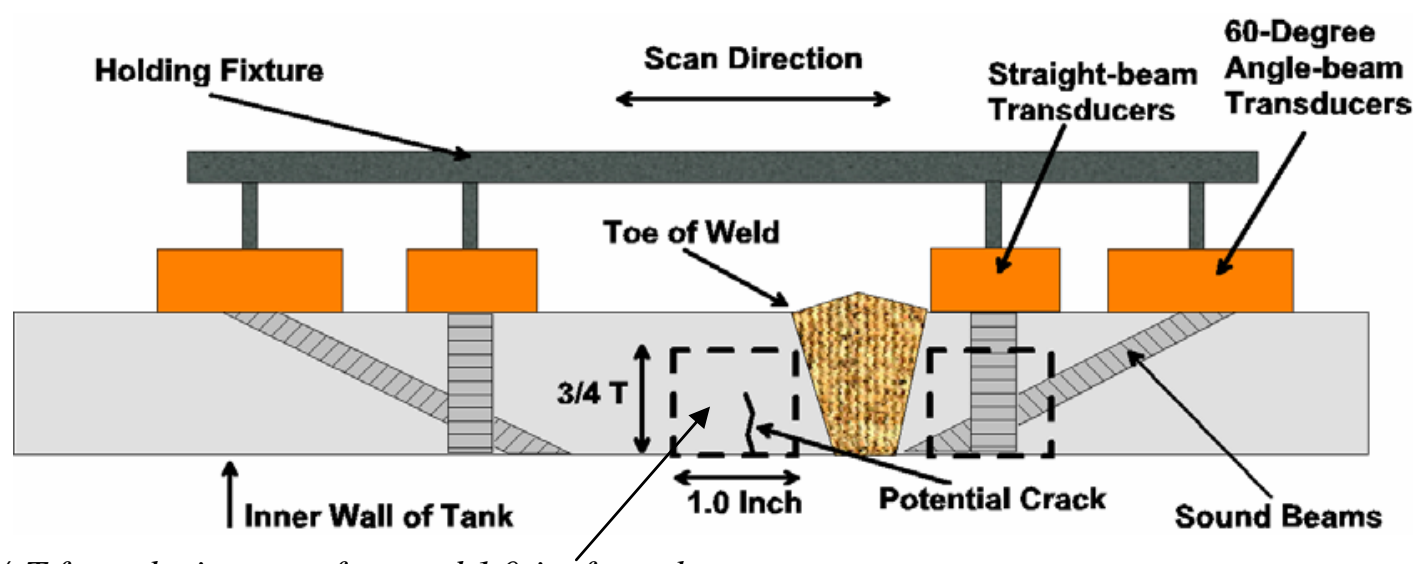

A zone $3 / 4 \mathrm{~T}$ from the inner surface and 1.0-in. from the toe of the weld is to be ultrasonically examined for cracking, corrosion or pitting. Examinations are to be made on both sides of the weld.

$$
\text { End View --- Cracks Parallel to the Weld }
$$

Figure 3.3. Views of the Weld Zone to be Ultrasonically Examined in the Primary Tank Wall 


\subsection{Ultrasonic Examination Location}

Tank 241-SY-102 is located in the Hanford 200 West area in SY Tank Farm. The crawler and associated scanner that hold the transducers were lowered into the 24-in. riser located on the west side of 241-SY-102 and designated as Riser 27. Figure 4.1 provides a graphic of the location of this riser.

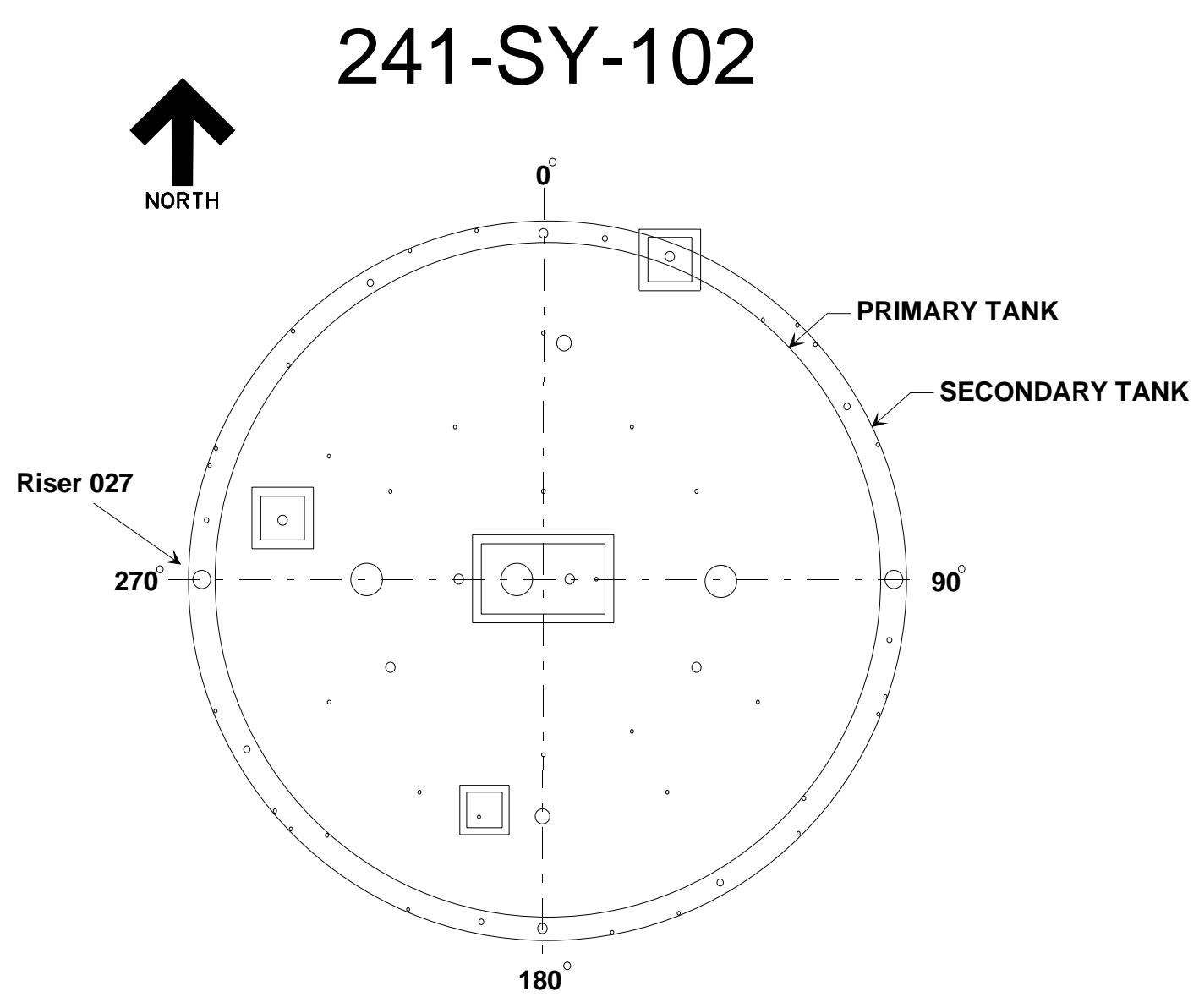

TANK RISER LOCATION

Figure 4.1. UT of 241-SY-102 from Riser 27 
Figure 4.2 describes the areas on the primary wall of Tank 241-SY-102 that were ultrasonically examined. Two 15-in.-wide vertical scan paths were performed on shell courses \#1, \#2, \#3, \#4, and \#5 below the entrance to Riser 27. Vertical weld HAZ examinations were done on shell courses \#1, \#2, \#3, $\# 4$, and \#5, and the horizontal weld HAZ examination was done on the transition shell course \#5 to knuckle weld.

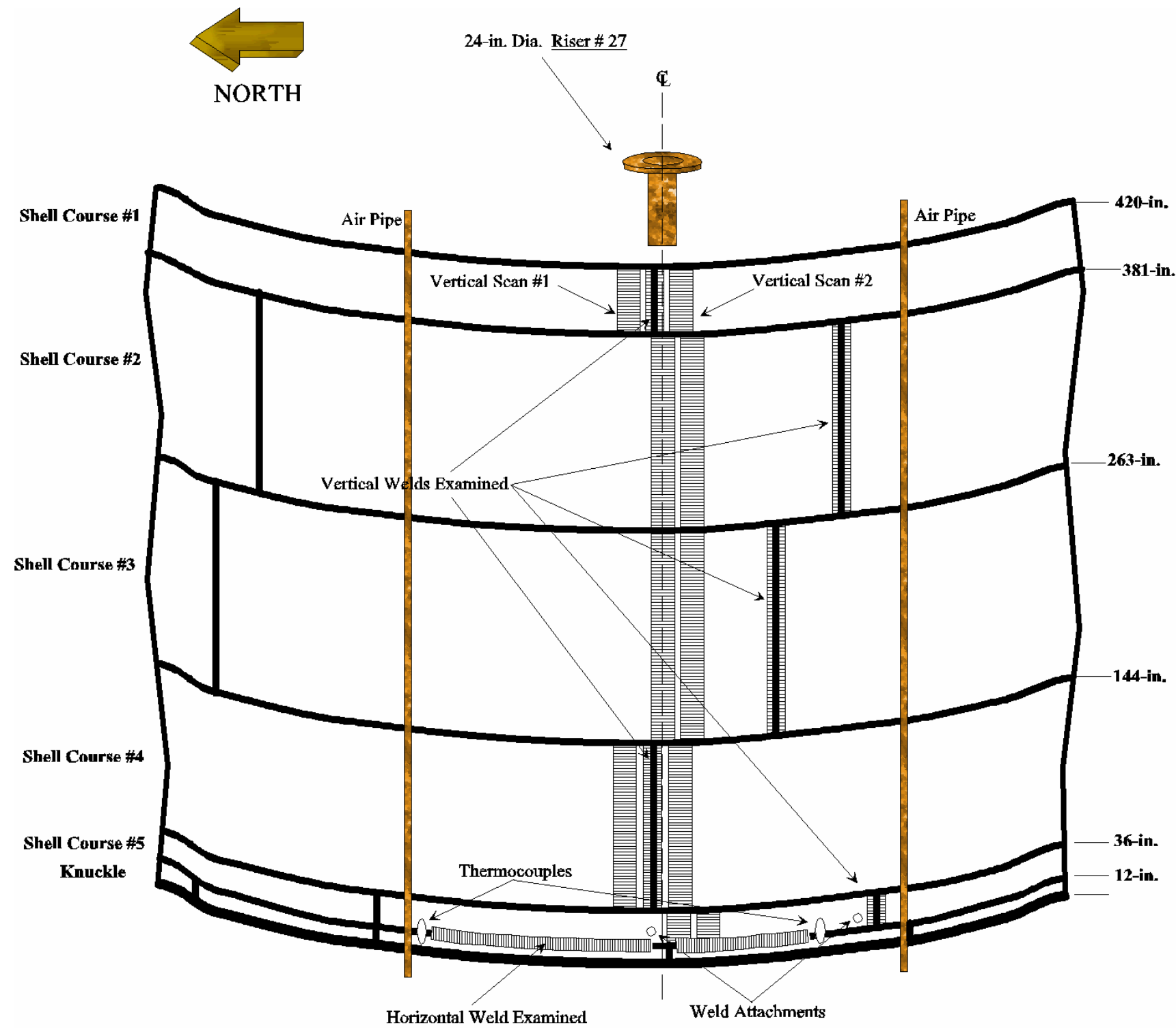

Figure 4.2. Sketch of Scan Paths on Tank 241-SY-102 


\subsection{Ultrasonic Examination Results}

COGEMA has provided detailed reports including T-Scan and P-Scan hard copies of all areas that were ultrasonically examined to PNNL for third-party review. The data was analyzed by COGEMA Level III Mr. Wes Nelson and by JBNDT Level III Mr. Jim Elder. The results of the examination of Tank 241-SY-102 are presented in Figures 5.1 and 5.2.

Figures 5.1 and 5.2 show the wall thickness examination results for the primary tank wall and the HAZs of both vertical and horizontal welds. The examination consisted of two vertical paths beneath the 24-in. diameter riser. Vertical scan \#1 was 15 -in. wide on shell courses \#1, \#2, \#3, \#4, and \#5 and started near the centerline of the 24-in. riser. Vertical scan \#2 was adjacent to vertical scan \#1 (except in shell courses \#1 and \#4 where they were separated by a vertical weld) and was also 15 -in. wide on shell courses \#1, \#2, \#3, \#4, and \#5. The HAZs of vertical welds in shell courses \#1, \#2, \#3, \#4, and \#5 were examined and the HAZ in the horizontal weld between shell course \#5 and the knuckle section was also examined. Areas in the figures that show two measurements in the same box are the result of the vertical scan paths overlapping the horizontal HAZ scan paths. Figures 5.1 and 5.2 display the minimum readings taken in each 15-in. wide by 12-in. long area of the scan. In the overlapping areas, both minimum readings from each of vertical and horizontal scan paths are given. The highlighted areas in shell course \#1 show minimum wall thickness exceeded the reportable level of $10 \%$ of the nominal thickness. 


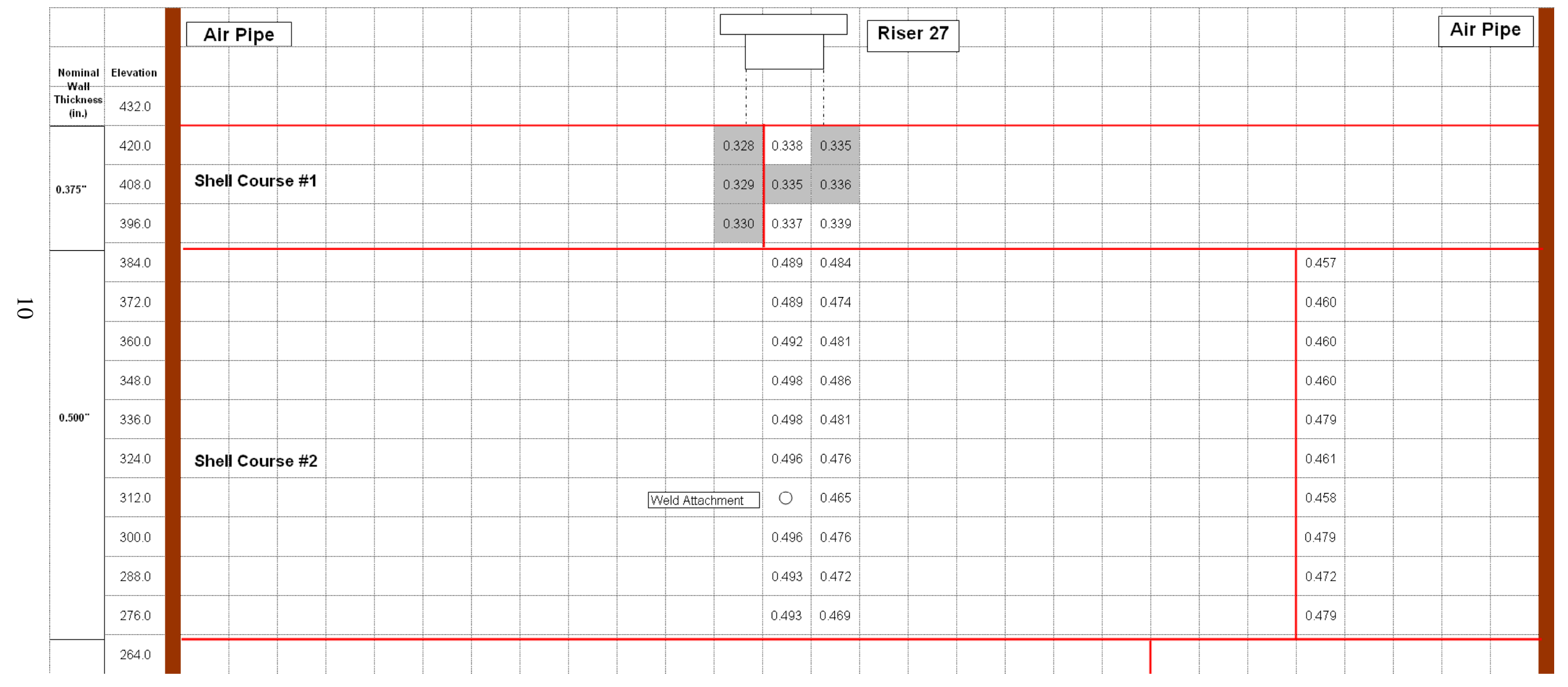

Figure 5.1. UT Data from Tank 241-SY-102 


\begin{tabular}{|c|c|c|c|c|c|c|c|c|c|c|c|c|c|c|c|c|c|c|c|c|c|c|c|c|c|c|}
\hline \multirow{10}{*}{$0.500 "$} & 264.0 & & & & & & & & & & & & 0.483 & 0.477 & & & & & & & 0.500 & & & & & \\
\hline & 252.0 & & & & & & & & & & & & 0.491 & 0.477 & & & & & & & 0.503 & & & & & \\
\hline & 240.0 & & & & & & & & & & & & 0.489 & 0.484 & & & & & & & 0.506 & & & & & \\
\hline & 228.0 & Air Pipe & & & & & & & & & & & 0.497 & 0.483 & & & & & & & 0.502 & & & & & Air Pipe \\
\hline & 216.0 & & & & & & & & & & & & 0.486 & 0.479 & & & & & & & 0.474 & & & & & \\
\hline & 204.0 & \multicolumn{2}{|c|}{ Shell Course \#3 } & & & & & & & & & & 0.499 & 0.489 & & & & & & & 0.506 & & & & & \\
\hline & 192.0 & & & & & & & & & & & & 0.493 & 0.492 & & & & & & & $\mid 0.507$ & & & & & \\
\hline & 180.0 & & & & & & & & & & & & 0.494 & 0.493 & & & & & & & 0.509 & & & & & \\
\hline & 168.0 & & & & & & & & & & & & 0.501 & 0.495 & & & & & & & 0.506 & & & & & \\
\hline & 156.0 & & & & & & & & & & & & 0.493 & NR & & & & & & & 0.512 & & & & & \\
\hline \multirow{9}{*}{$0.750^{\prime \prime}$} & 144.0 & & & & & & & & & & & 0.742 & 0.736 & 0.731 & & & & & & & & & & & & \\
\hline & 132.0 & & & & & & & & & & & 0.753 & 0.741 & 0.739 & & & & & & & & & & & & \\
\hline & 120.0 & & & & & & & & & & & 0.753 & 0.740 & 0.737 & & & & & & & & & & & & \\
\hline & 108.0 & & & & & & & & & & & 0.752 & 0.737 & 0.722 & & & & & & & & & & & & \\
\hline & 96.0 & \multicolumn{2}{|c|}{ Shell Course \#4 } & & & & & & & & & 0.753 & 0.747 & 0.735 & & & & & & & & & & & & \\
\hline & 84.0 & & & & & & & & & & & 0.747 & 0.734 & 0.735 & & & & & & & & & & & & \\
\hline & 72.0 & & & & & & & & & & & 0.753 & 0.744 & 0.739 & & & & & & & & & & & & \\
\hline & 60.0 & & & & & & & & & & & 0.749 & 0.736 & 0.731 & & & & & & & & & & & & \\
\hline & 48.0 & & & & & & & & & & & 0.740 & 0.747 & 0.731 & & & & & & & & & & & & \\
\hline \multirow{2}{*}{$0.875 "$} & 36.0 & \multicolumn{2}{|c|}{ Shell Course \#5 } & & & & & & & 1 Alla & & & 0.846 & 0.835 & & & & & & & & & \multicolumn{2}{|c|}{$\frac{1}{\text { Weld Attachment }}$} & 0.852 & \\
\hline & 24.0 & \begin{tabular}{|c|} 
Thermocouple \\
\\
0.885 \\
\end{tabular} & 0.880 & 0.886 & 0.874 & 0.885 & 0.873 & 0.876 & 0.884 & 0.885 & 0.892 & $\begin{array}{c}0 \\
0.884\end{array}$ & $\begin{array}{l}0.848 \\
0.886 \\
\end{array}$ & \begin{tabular}{|l|}
0.847 \\
0.889 \\
\end{tabular} & 0.888 & 0.891 & 0.885 & 0.881 & 0.877 & 0.880 & 0.881 & 0.871 & 0.868 & $\Omega^{0}$ & 0.860 & \\
\hline $0.875^{\prime \prime}$ & 12.0 & $\begin{array}{l}0.859 \\
\text { Knuckle }\end{array}$ & 0.860 & 0.871 & 0.852 & 0.853 & 0.861 & 0.866 & 0.865 & 0.861 & 0.856 & 0.859 & 0.852 & 0.868 & \begin{tabular}{|l|}
0.838 \\
\end{tabular} & 0.842 & 0.850 & 0.830 & 0.825 & 0.834 & 0.837 & 0.839 & 0.838 & Thermocou & & \\
\hline
\end{tabular}

Figure 5.2 UT Data from Tank 241-SY-102 cont. 


\subsection{Conclusions}

The results of the examination of Tank 241-SY-102 have been evaluated by PNNL personnel. The examination consisted of two 15-in. wide scans over the entire height of the tank and the HAZs of 5 vertical welds and 1 horizontal weld. The examination was performed to detect any wall thinning, pitting, or cracking in the primary tank wall.

\subsection{Primary Tank Wall Vertical Scan Paths}

Two 15-in.-wide scan paths were performed on shell courses \#1,\#2,\#3,\#4, and \#5. The shell courses were examined for wall thinning, pitting, and cracks oriented vertically on the primary tank wall. The results indicated that the nominal thickness in shell course \#1 was 0.375-in. and the minimum thickness was 0.328-in. The minimum thicknesses in the areas scanned with nominal thickness of 0.500in. were as follows; shell course \#2 was 0.465 -in. and shell course \#3 was 0.477 -in. The nominal thickness in shell course \#4 is 0.750-in. and the minimum thickness in this area was 0.722 -in. The nominal thickness in shell course \#5 is 0.875 -in. and the minimum thickness in this area was 0.835 -in. There were 5 areas of wall thinning that exceeded the reportable level of $10 \%$ of the nominal thickness. These areas were all located in shell course \#1. No pitting or vertical crack-like indications were detected in shell courses \#1, \#2, \#3, \#4, or \#5.

\subsection{Primary Tank Wall Weld Scan Paths}

The HAZ of vertical welds in shell courses \#1, \#2, \#3, \#4, and \#5 were examined for wall thinning, pitting and cracks oriented either perpendicular or parallel to the weld. The results indicated that the minimum thicknesses in the weld areas scanned were as follows: The nominal thickness of shell course \#1 is 0.375 -in. and the minimum thickness in this weld area was 0.335 -in. The nominal thickness of shell course \#2 is 0.500 -in. and the minimum thickness in this weld area was 0.457 -in. The nominal thickness in shell course \#3 is 0.500-in. and the minimum thickness in this weld area was 0.474-in. The nominal thickness in shell course \#4 is 0.750-in. and the minimum thickness in this weld area was 0.734-in. The nominal thickness in shell course \#5 is 0.875-in. and the minimum thickness in this weld area was 0.852in. There was one area of wall thinning that exceeded the reportable level of $10 \%$ of the nominal thickness. The area was located in shell course \#1. No pitting or crack-like indications were detected in the weld HAZ areas in shell courses \#1, \#2, \#3, \#4, and \#5.

The HAZ of the horizontal weld between shell course \#5 and the tank knuckle was examined for wall thinning, pitting and cracks oriented either perpendicular or parallel to the weld. The results indicated that the minimum thickness in the weld area with nominal thickness of 0.875 -in. on shell course \#5 was 0.871-in. The minimum thickness in the weld area with nominal thickness of 0.875 -in. on the knuckle was 0.825 -in. There were no areas of wall thinning that exceeded the reportable level of $10 \%$ of the 
nominal thickness. No pitting or crack-like indications were detected in the weld areas on shell course \#5 side or on the knuckle side of the horizontal weld. 


\subsection{References}

Jensen, C. E., 2003, Engineering Task Plan for the Ultrasonic Inspection of Hanford Double-Shell Tanks FY2004, RPP-17750, Rev 0, September 2003, CH2M Hill Hanford Group, Inc., Richland, Washington. 


\section{Distribution}

No. of

Copies

Offsite

1 DOE Office of Science and

Technology

Kurt Gerdes

1154 Cloverleaf Building

19901 Germantown Road

Germantown, MD 20874-1290

\section{Onsite}

\section{Hanford Site}
J. L. Castleberry (1)
R3-76
C. E. Jensen (2)
R3-76

8 Pacific Northwest National Laboratory
T. T. Taylor (1)
K5-26
M. T. Anderson (1)
K5-26
A. F. Pardini (5)
K5-26
G. J. Posakony (1)
K5-26 